SHS Web of Conferences 24, 02015 (2016)

DOI: $10.1051 /$ shsconf/20162402015

(c) Owned by the authors, published by EDP Sciences, 2016

\title{
An in-depth study of undergraduate tutorial system based on education and teaching integration reform
}

\author{
Wenhui Fan \& Yang Han* \\ School of Mechanical Engineering, Beijing Institute of Technology, Beijing, China
}

\begin{abstract}
As personalized development for undergraduate is the trend of higher education development, the undergraduate tutors should play their role in the establishment of personalized personnel training mode. Based on reform practice of university education integration, this article gives a deepening research on the essence and implement methods of undergraduate tutorial system. To implement and strengthen the function of undergraduate tutorial system, we need to increase teachers' comprehensive quality training, build a multiple-dimension, full-process and whole-staff-participation educational concept, absorb the enterprise mentors to give guidance on students' career planning and implement the scientific and reasonable undergraduate administrative evaluation system. With continuous theory exploration and practice research, the quality of undergraduate talent training has been gradually improved.
\end{abstract}

Keywords: education integration; undergraduate tutor; in-depth study; personalized development

\section{INTRODUCTION}

With continuously strengthening the cultivating pattern of college talents reform intensity, teaching staff gradually realized that personalized development is the key method for increasing the undergraduate cultivation quality, while building personalized personnel training mode requires their tutors plays the important role on it. It has been more than half of the century for the implementation of the tutorial system in China, which promotes our countries higher education development objectively, cultivating a large number of outstanding talents. However, in the context of higher education popularization tutorial system characterized by personalized elitist education, there is some "unaccustomed" conditions occurring during the implementation process. Under this background, with the basis of education integration and the guidance of deepening undergraduate tutorial research, it has the important theoretical value and practical meanings to build personalized personnel training mode in improving the undergraduate talent training quality.

*Corresponding author: hanyang0316@126.com

\section{RELEVANT BACKGROUND INFORMATION}

\subsection{Students' personalized development is the trend} of higher education

In the traditional western higher education, the emphasis on academic in the British institution of higher education, the concentration on scientific research in Germany universities, the cultivation for interest in America universities all have great impact for our country's higher education development, which also has especially shock on our country's yearly stressing in "quality-oriented education". It is undeniable that China's education quality is apparently higher than those western countries in basic education, especially in "elementary school, junior high school and senior high school", but our higher education is far behind for several levels compared with western countries. Traced its reason, it is because the higher education requires "T" character pattern talents instead of "+" character pattern talent. What they need is "Top talents", rather than "Wooden barrel effect" and "short board effect" emphasized in teamwork.

Facing with China's strong call for cultivation of innovative talents and outstanding talents, inspiring students personalized development is an inevitable trend in higher education, a core goal to increase un- 


\section{SHS Web of Conferences}

dergraduate teaching training quality, as well as the indispensable fertile soil for training innovative talents. In December, 2004, in the article of several advice on further strengthen undergraduate teaching work in institution of higher education, the Ministry of Education has clearly point out that: "For those qualified institutions of high education, they should actively carry out tutorial system, trying hard to provide excellent and personalized service for students development in an all-round-way." It is a breakthrough for higher education reform with the educational concept of "imparting knowledge and education, people oriented, teaching benefits teachers as well as students" emphasized in undergraduate tutorial system. Researcher David Palfreyman from Oxford University even further points out that for generations of outstanding undergraduates in the future need strictly tutorial system to temper academic basic skill in order to calmly cope with the career life and social variance.

\subsection{The current situation and problems of our country's undergraduate tutorial system}

We have trial implemented the undergraduate tutorial system before the establishment of New China. In 1937, Coching Chu has pioneered the undergraduate tutorial system in Zhejiang University according to Havard University. The tutorial system is an individual guidance method for education according to the goal of talent cultivation and specification requirements.

Wang Wei Qi and others classified undergraduate tutorial system into scientific research tutorial system, elite student tutorial system and absolute tutorial system; Li Rui also has the similar classification but not identical during the research, mainly reflecting on the classification of absolute tutorial system and elite student system according to training objects, which is similar in meaning. It can be seen that currently there is a big different opinion about China's undergraduate tutors. Some scholars thinks that the undergraduate should inherit the trait from the postgraduate tutors for cultivating students scientific research capacity; while others consider that undergraduate tutors should also develop their moral education ability. During the practice, undergraduate tutor system's formal meaning is always greater than the real value in the promotion process of undergraduate teaching quality system, with unclear position in operation, uncertain responsibility, insufficient fund, low enthusiasm and weak supervision. The ideological consensus of undergraduate tutorial system is urgent to come to an agreement. The writer holds the opinion that no matter for training the students' scientific research capacity or moral education quality; it is just different emphasis point. As all roads lead to Rome, the core mission for higher education is to cultivate high quality and top-notch talents, so the undergraduate tutorial system should serve for this goal.

\subsection{Higher education integration reform creates the good condition for undergraduate tutor in-depth study}

There is a disconnection between students ideological and political education, daily management and teaching program for some colleges and universities in the talent cultivation process, which makes students education administrative department only concern about students ideological and political education and management, while teaching sectors only focus on students course learning. This brings the great disadvantage for talent cultivation and is difficult to form the join force. Therefore, a lot of colleges and universities hope to seek and explore a mode integrated with resources of education, teaching, and scientific research, etc. in pushing the realization of "education by all staff" and teaching quality promotion, which is teaching integration reform. The so-called college and university education integration means many crossover and fusion measures adopted in mechanism for accelerating talent-training quality, especially for the comprehensive quality-oriented education. It is the detailed work intersection research between scientific research, teaching, students' ideology and politics education and management in school, so this is also called "education and teaching integration".

With the combination of theory and practice, the writer explores the in-depth study of undergraduate tutorial system based on the education integration in School of Mechanical and Vehicle in Beijing Institute of Technology, especially on the practice efficiency of students' education management department and teaching sectors integration construction. The writer hopes to improve quality-oriented education quality and students personalized development, cultivating the higher education talents in physical development, pushing students' comprehensive quality integrated development.

\section{IN-DEPTH DEVELOPMENT OF UNDERGRADUATE TUTORS FOR IMPROVING UNDERGRADUATE CULTIVATION QUALITY AND STUDENTS PERSONALIZED DEVELOPMENT}

\subsection{Strengthening teachers' comprehensive cultivation, especially in teachers' ethics promotion is the basic requirements for undergraduate tutors to play their roles}

The performance in morality, culture and ability and accomplishment of teachers in universities and colleges will directly restrict teachers' teaching and education quality, consequently influencing higher education function. Confucius once said, "If the ruler is personally upright, all will go well even though he does not give orders. But if he is not personally upright, even though he gives orders, they will not be 
obeyed." Coching Chu holds the opinion that "The best education is setting an example to others. This theory can be applied no matter in institutions, academy of classical learning in ancient times or current new-style university. Since the undergraduate tutors are direct models for college students in manners of human being, the tutors' quality has the direct influence on them. As teachers of universities and colleges, they should instruct and influence students by their words and deed. For imparting the professional knowledge, they should influence them with their own life criteria and attitude, giving a positive effect to students' physical and psychological quality as well as ideological self-cultivation.

Colleges and universities should regard teacher's ethics as the first priority for construction of teaching staff, taking "education and teaching integration" mechanism as starting point, strengthening the combination with educators and teaching staff, promoting the moral level of the faculty, taking the teachers noble ethics as means of education, pushing college students quality improvement by teachers high-quality. What we can discover from the research is that the students have multi-aspect requirements for undergraduate tutors. They expect to learn true skill and genuine knowledge from tutors, obtaining "positive energy" from the tutors to encourage and charge themselves, and they even expect tutors can give them the right directions like the elder. It is clear that the undergraduate tutors ethics quality should reflect on carefully teaching and leading guidance, delivering the firm political stand, noble moral character, tenacious attitude towards life, good life sentiment to students, conveying "Great Love" and "Positive Energy" to them, and only this can live up to the honorable title of "People's Teacher". A man of true worth attracts admiration. Fully paying attention to teacher's ethics quality leading role is undergraduate tutorial system's basic protection.

Table 1. The requirements from students to undergraduate tutors

\begin{tabular}{|l|l|l|}
\hline No & Point of view & percentage \\
\hline 1 & $\begin{array}{l}\text { Hope to obtain professional cogni- } \\
\text { tion and guidance }\end{array}$ & $89 \%$ \\
\hline 2 & $\begin{array}{l}\text { Hope the tutors can deliver warm to } \\
\text { students }\end{array}$ & $72 \%$ \\
\hline 3 & $\begin{array}{l}\text { Hope the tutor is a very learned and } \\
\text { well-informed scholar }\end{array}$ & $59 \%$ \\
\hline 4 & $\begin{array}{l}\text { Hope the tutor is a good-tempered } \\
\text { elder }\end{array}$ & $45 \%$ \\
\hline
\end{tabular}

\subsection{Multiple-dimension, full process,} whole-staff-participation educational concept is the qualified teachers guarantee for undergraduate tutorial system to play its role

To play the role of undergraduate tutorial system requires abundant qualified teachers. According to the data from Oxford official website in 2010 , there are about nine thousand students in total and five thousand four hundred of the teaching and administrative staff. In China, the universities and colleges require counselors and students in the proportion of 1:200, but it cannot reach the standard during practice. Under the premise of gradually popular high education in China, it seems unreachable to guarantee every student has the tutor. Be sure to have enough faculties to guarantee the undergraduate tutorial system to play its role. This requires developing multiple-dimension, full process, and whole-staff-participation educational concept by using the education and teaching integration reform opportunity, breaking the limitation from educational administration department and teaching training development, providing guarantee to the undergraduate with different aspect of faculties.

Therefore, the "tutor" should not limit its essence of the undergraduate tutorial system. The undergraduate tutors are different from postgraduate tutors who can be served by doctoral students or lecturers even the postgraduate student. Because the undergraduates need the fundamental major instruction and career planning, senior postgraduates are capable to provide those help and guidance. Meanwhile, with the guarantee of education and teaching integration mechanism, the students will get the faculties support from all aspects during their schooldays, for example, the faculty advisers for technological innovation, theory of tutors from party branch, faculty advisers for student's organization. All these are the important guarantees for undergraduate tutorial system to play its role. Prompted by the whole-staff-participation education concept, School of mechanical and vehicle from Beijing Institute of Technology has achieved preliminary success on education and teaching integration reform practice. Among the undergraduate tutors in the school, the undergraduate faculty's quality is guaranteed with senior titles and deputy high titles of teachers reaching fifty percent.

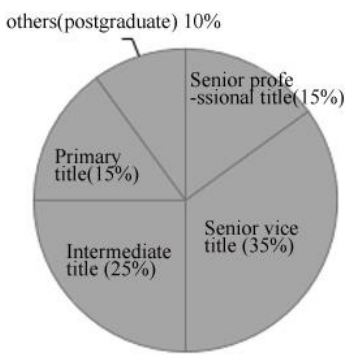

Figure 1. Undergraduate student tutor professional title distribution

3.3 Absorbing the enterprise tutors to counsel for the career planning is the important complement for undergraduate tutorial system to play its role

When undergraduates enter the society, generally, 
SHS Web of Conferences

Table 2. 2015 undergraduate data of school of mechanic and vehicle

\begin{tabular}{|l|l|l|l|l|}
\hline \multirow{3}{*}{ Year } & Total graduate number & orientation & Employability & To postgraduate \\
\cline { 2 - 5 } & 428 & 21 & 407 & 136 \\
\hline \multirow{2}{*}{2015} & Go abroad & Sign contract & Sign contract rate & Employment rate \\
\cline { 2 - 5 } & 116 & 130 & $94.63 \%$ & $97.66 \%$ \\
\hline
\end{tabular}

Table 3. The difficulty of implementation of undergraduate student tutor system

\begin{tabular}{|l|l|l|}
\hline number & Difficulty & Percentage \\
\hline 1 & $\begin{array}{l}\text { Quality-oriented education is difficult to produce results comparing } \\
\text { with academic research. }\end{array}$ & $89 \%$ \\
\hline 2 & $\begin{array}{l}\text { It lacks scientific reasonable evaluation system and cannot get } \\
\text { others' approval at work. }\end{array}$ & $72 \%$ \\
\hline 3 & $\begin{array}{l}\text { Training needs to be provided for schoolteachers due to limited } \\
\text { teaching experience. }\end{array}$ & $31 \%$ \\
\hline
\end{tabular}

they need a period to adapt to their career. Interpersonal skill, document writing skill, communication and presentation skills, and collaboration ability can be self-cultivated during college period. As a rule, those undergraduates who can quick adapt to the career can also get rapid growth. Arranging the enterprise tutors can give the students different guidance in different growing periods. As the participation of enterprise tutors, students can contact the society and industry ahead of time with better training opportunity for application ability and professional quality.

For this reason, universities and colleges should expand the undergraduate tutors' connotation, actively absorbing enterprise tutors and developing career planning consultation and professional guidance with the alumni resources. Taking School of mechanical and vehicle from Beijing Institute of Technology as an example, they integrate alumni service, career guidance, career planning, etc. together with the establishment of career service center, which can both serve for the alumnus and undergraduates' career planning. For example, school will carry out enterprise lecture every year before the recruitment season, inviting the alumnus from relevant enterprise to explain their career and industry. Particularly, nowadays when China vigorously promote university students innovative undertaking, the enterprise lecture attracts numerous entrepreneur alumnus serving as enterprise mentors to teach students by their personal example as well as verbal instruction and explain them how to combine the major knowledge with starting a business. With its good effect, the school graduate quality has improved year by year. In 2015, the undergraduate employment rate reaches $97.66 \%$, state-owned enterprise and large-scale enterprise ratio of more than $70 \%$, Beijing, Shanghai, Guangzhou ratio of more than 67\%; Liu Di is one of 2013 graduate student who transferred the technology to productivity. He founded Beijing Worker Industry Technology Development co., LTD, which is the supplier of Formula races China.

\subsection{Implementation of scientific and reasonable} undergraduate student tutorial management evaluation system is the mechanism guarantee for putting undergraduate student tutorial system into full play.

How to handle the relationship between undergraduate tutors and counselors is likely to be a challenge for educators during the practice of undergraduate tutorial system. Although tutors and counselors have different responsibilities, their jobs are two aspects of one task. They are both educators for students, whose role is to cultivate and develop high-quality research-typed talents based on talents developing plan of universities. They take the same responsibility of training students. One student has the multiple relations with counselor, head teacher and adviser, but how to nurture trust on every teacher that requires maximizing the complementary and mutual interaction between tutors and counselors on the work of undergraduate student training. Increasing the communication between tutors and counselors, the tutors and counselors will understand timely for students' requirements with a clear division of labor. The tutors give full play to their specialty to guide students regarding on academic work. The counselors educate students on ideology and politics, morality as well as sound personality education, which can yield twice the result with half of the effort. School of mechanical and vehicular of Beijing Institute of Technology will organize and hold "tutors and counselors annual working meeting" at the end of year every year, constructing communication bridge between undergraduate students tutors and counselors, exploring together various problems encountered from educational practice, developing individualized training scheme according to individual students.

On the other hand, education management department establishes the comprehensive evaluation system for undergraduate student tutors, which reflects correctly teachers' effectiveness on education guidance 
work. It is not only the validation and encouragement for advanced educational workers, but also a motivation for masses of educational workers. Research group investigation shows that the difficulty of implementation of undergraduate student tutorial system lies in lack of scientific and reasonable evaluation system for teachers' educational work. Education is not so easy to have results like academic research, which leads to some teachers focus on scientific achievements and pay less attention on educational work.

For undergraduate student tutors, apart from guaranteeing the guidance and help to students, they should pay special attention to their moral character, which requires tutors to set an example and teach through words and actions. They should also have an active participation on student activity, showing concern for student growth; the overall condition will not only bring into annual performance assessment but also reflect in professional-title evaluation. Universities can set up honor and reward for commending outstanding educators, encouraging prominent contributors during the quality-oriented education, setting up excellent examples, leading more teachers to participate moral education. For example, School of mechanical and vehicular of Beijing Institute of Technology carries out "teacher morality one-vote negation system and "education comprehensive evaluation system", and student union also organize the activity that selecting and rewarding "The most beautiful teacher in my heart" every year, which gains the popularity among teachers.

\section{CONCLUSION}

College students' quality education is the primary task of current higher education, obviously playing an important role in cultivating high-quality modern talents with a sense of responsibility. For higher education, to give its full play on quality-oriented education, one have to pay high attention on undergraduate students tutorial system, studying in depth on system and teachers guarantee or other factors for undergraduate tutors. Take the multiple-dimension, full process, and whole-staff-participation educational concept as teachers guarantee as well as enterprise mentors as an important supplement on the basis of education integration, setting up scientific and reasonable evaluation system as system guarantee. Strive to carve out a new ground of undergraduate student tutor, with an effort to cultivate the qualified constructors and successors who are well developed intellectually and physically for the socialist cause. The study and practice of undergraduate students tutor system get a long way to go, which requires higher school educators moving forward with great diligence and courage.

\section{REFERENCES}

[1] [En] Palfreyman. 2013. Thanks, You Taught me How to Think. Beijing: Peking University Press, 2011:29.

[2] Baojian Chen. Tutorial system is an effective means improving undergraduate comprehensive abilities. China Adult Education. (9).

[3] Lifang Ye. 2007. Harvard University's deep analysis on Coching Chu's educational thoughts influence. Journal of Higher Education Management, (3).

[4] Weiqi Wang \& Xinrong Huang. 2007. Analysis on implementing undergraduate tutorial system under the new circumstances. Jiangsu Higher Education, (5).

[5] Taipeng Wang, Yanyan \& Wenhui Fan. 2013. Reform and practice of undergraduate education integration. 2013 colleges and universities education and teaching conference proceedings (CETCU2013): 219-222.

[6] Li Rui. 2011. Analysis on Implementation and Optimization of Undergraduate Tutorial System. Kaifeng: Henan University.

[7] Wenyaun Li. 2013. Undergraduate tutorial system--An imperative system. Education Forum, (8).

[8] Feng Hao \& Chang Hai. 2015. Current situation of implementation and main orientation of undergraduate tutorial system of colleges and universities in China .Journal of Shenyang University (Social Science) (2).

[9] Zhang Zheng. 2015. Exploration on practical route of enterprise mentors of colleges and universities. China Adult Education. (11).

10] Zhou Qing, Jiefeng Wang \& Hu Jia. 2014. Evaluation model innovation of undergraduate tutorial system--Based on practical exploration of undergraduate tutorial system at Ningbo Universities. Higher Education Development and Evaluation. (4). 